Session 2530

\title{
A Combined Engineering and Education Class at the University of Oklahoma: Preparing Authentic Science and Math Educators
}

\author{
Teri Reed Rhoads ${ }^{\mathrm{a}}$, Mark Nanny ${ }^{\mathrm{b}}$, and Mary John O'Hair ${ }^{\mathrm{c}}$ \\ The University of Oklahoma \\ ${ }^{\text {a }}$ School of Industrial Engineering \\ ${ }^{b}$ School of Civil and Environmental Engineering \\ ${ }^{c}$ Center for Educational and Community Renewal and the College of \\ Education
}

\begin{abstract}
One result of the receipt of a National Science Foundation Graduate K-12 Fellows grant at the University of Oklahoma is a combined engineering and education class. The goal of this upper division or graduate credit course is to prepare authentic science and math educators by providing both the educational theory and the scientific knowledge to prepare authentic classroom exercises in the K-12 environment. This paper reviews the course demographics, goals, content, and execution of the first offering of this course in fall of 2001. A discussion of the combination of education majors with engineering majors and a presentation of a combined curriculum is presented. This course is not only a model for other NSF GK-12 projects, but other universities interested in bridging the gap between education and engineering.
\end{abstract}

\section{Introduction}

In March of 2001, the National Science Foundation awarded 24 projects nation-wide in its Graduate Fellow K-12 (GK-12) program. Of those awarded, 5 states received two awards. The University of Oklahoma is the only institution to have received two awards - the Authentic Teaching Alliance (ATA) and Adventure Engineering (AE). The long term goals of the initiative are to increase the number of secondary math and science teachers, increase the number of secondary students choosing careers in science engineering and technology, and increase the public's science and math knowledge.

A potential shortage of qualified K-12 teachers is a looming educational crisis. The National Center for Education Statistics estimates, for the coming decade, a teacher attrition rate of $7 \%$ and $12 \%$ in public and private schools respectively. The "graying" of the current teaching force, and the strong economy luring teachers away to more lucrative fields causes this attrition. Other

Proceedings of the 2002 American Society for Engineering Education Annual Conference \& Exposition Copyright (C) 2002, American Society for Engineering Education 
government projections estimate that the demand for secondary teachers (primarily science and math) will increase by $22 \%$. On the other hand, the U.S. Census Bureau projects that student enrollment for ages $5-13$ will increase by $12 \%$, and $28 \%$ for ages $14-17^{1}$.

In response to teacher shortages, many communities and states have resorted to hiring educators from other countries, lowering teaching certification standards, and staffing science and mathematics courses with unqualified teachers who don't have a major or minor in the field. The later two items are most troubling in light of the recent quantitative research by DarlingHammond ${ }^{2}$ indicating "that measures of teaching preparation and certification are by far the strongest correlates of student achievement in reading and mathematics, both before and after controlling for student poverty and language status."

In this context, ATA was developed to educate, nurture, and facilitate science and technology university students into bringing their experiences and knowledge into the classroom and become educators. However, ATA does not stop here. It recognizes that effectives student education requires authentic and inquiry-based learning. Students must be able to link the relevance of their education with the events and issues occurring in their community and their world. In addition, students must be able to experience how their education allows them to participate as effective citizens in a technology-based society. ATA prepares future science and mathematics educators who are capable of authentic teaching.

One important aspect of the project is the training provided to the Fellows. A Fellow is defined as a participant in the project that is a graduate student (either Masters or $\mathrm{PhD}$ ) or a senior or junior (therefore, upper level) undergraduate student. The method chosen to train these Fellows for this project was through an actual course offering in a regular fall semester format. Some of the other methods chosen by others with similar grants are one and two week "crash" courses or full summer sessions. The first offering of this course is discussed along with initial results and future changes. This course serves as a potential model in the engineering education arena.

\section{Goals and Objectives of ATA}

ATA has two main goals. The first is to produce scientists, engineers, and secondary science and mathematics educators who are experienced in developing and implementing authentic educational practices into secondary science and mathematics curricula. In addition, these students will bring their technical background and expertise into the secondary classroom in a meaningful and edifying manner. They will be exemplary in their ability to enhance and reinforce basic scientific and mathematical concepts by integrating inquiry-based, open-ended problems pertinent to the student's community. Even if every Fellow does not pursue a traditional teaching career, their participation in ATA will be beneficial for education as a whole as they continue forming partnerships between education, business, and the community. These Fellows may inspire their corporations and businesses to become directly and/or financially involved with local schools, they may decide to bring their technological expertise into the classroom through 
substitute or part-time teaching, or they may incorporate their acquired teaching skills into designing effective and user-friendly technology.

The second goal is to design, develop, and implement hands-on activities and inquiry-based projects related to an issue or topic pertinent to the students' community as a vehicle to authentically teach secondary science and mathematics skills. The idea is to enable secondary students to directly experience the relevancy of their education to "real-world" problems, as well as experience a direct link between their education and their community. Rather than didactically focusing on memorization of factual information, authentic learning requires that educators design and facilitate learning experiences that: engage students in personal construction of new knowledge; result in students conducting disciplined inquiry; and have value beyond the classroom $^{3}$. A study of over 1,500 secondary schools found that in classrooms where teachers taught authentically, students consistently outperformed students taught using more conventional methods ${ }^{4}$.

Relating to the Fellows, the objectives are:

- To engage Fellows in meaningful, productive, and innovative educational instruction and activities so they will become excited about, and motivated to teach science, mathematics, and engineering.

- To help Fellows realize and understand that the facets of education, research, and professional activities overlap, and that in fact, the Fellows can be more successful in their career when they overlap these activities.

- To have university faculty and staff, and secondary teachers, provide guidance, instruction, and mentoring to Fellows in the practice of educational pedagogy, educational research, and developing best teaching methods.

- To provide Fellows practical and direct experience in teaching secondary students.

- To have Fellows design, develop, and implement secondary-level, authentic, inquiry-based learning activities and projects, that are based on their technical expertise and knowledge.

- To train Fellows in the development and implementation of computer modules using current electronic multimedia tools.

Relating to the secondary teachers, students, and schools, the objectives are:

- To increase student learning in math and science.

- To directly incorporate secondary teachers into the teaching and mentoring of the Fellows.

- To implement hands-on, inquiry-based activities, into the secondary school science and mathematics curriculum, that are designed to enhance and reinforce basic concepts already taught in the secondary curriculum.

- To motivate students, through real-world experiments, observations, and measurements, to study problems that affect their daily lives.

- To use these activities to link students from different classes and schools, via peer teaching, collaborations, and the Internet, as they focus on common themes.

- To include computers and up-to-date sampling and laboratory equipment in all activities so

Proceedings of the 2002 American Society for Engineering Education Annual Conference \& Exposition Copyright (C) 2002, American Society for Engineering Education 
students gain experience with current technology.

- To incorporate computer-based, self-paced learning modules that will assist in solving computational problems, supply background information and data, and help facilitate execution of the projects.

- To motivate and educate teachers to use electronic multimedia for curriculum design.

\section{Recruitment and Selection of Fellows}

Engineering Fellows are recruited both locally and nationally. As well, science and mathematics education senior undergraduate and graduate Fellows are recruited, both locally and nationally. The rationale for including education Fellows is the same rationale for encouraging interactions between science and technology Fellows and K-12 teachers in the NSF Graduate Teaching Fellows in K-12 Education Program; integration of those who know how to teach with those who know the current science and technology produces a dynamic and exciting educational team. Likewise, pairing engineering Fellows with science and mathematics education Fellows will facilitate Fellows teaching each other about their respective areas, thereby enhancing the overall quality of the team and the produced activities. It is not enough to know science and technology to effectively teach; one must also know the best educational methods and practices in order to know how to teach effectively. Moreover, the peer interaction will give engineering Fellows a greater respect for education and teaching as a career. Likewise, the science and mathematics education Fellows will have first-hand experiences with current science and technology, thereby strengthening their scientific background and encouraging them to further their science education. As a result, they will become better science and mathematics teachers.

Interested students are asked to submit a standard application for being considered as a K-12 Fellow for the project, including transcripts from previously attended institutes, past experience, GRE scores (for graduate students) or ACT/SAT scores (for undergraduate students), three recommendations, a statement of education, and career goals and how participation in the proposed project will affect them. Members of the Project Committee screen applicants, including performing a background check through the state FBI. Highly qualified applicants who demonstrate a serious interest in the proposed project may be offered the opportunity to visit OU. In general, Fellowships are offered to applicants meeting the following criteria:

- Have excellent academic records in their current or previous program of study, as indicated by a cumulative grade point average of at least 3.3/4.0.

- Score of 1200/1600 (quantitative + verbal) on the GRE general test for graduate students, and an ACT score of 30 or a SAT score of greater than 1325 for undergraduate students.

- Show a strong interest in engineering, math, science, and math and science education pedagogy.

- Indicate plans to pursue graduate degree, preferably Ph.D., in engineering, environmental science, or math and science education.

- Identify areas of research interest related to the goals set in ATA.

Proceedings of the 2002 American Society for Engineering Education Annual Conference \& Exposition Copyright $($ C 2002, American Society for Engineering Education 
- Plan to pursue a career in teaching and/or research.

- Have strong letters of support.

Table No. 1 gives the basic demographic data of the Fellows participating in the course in the fall 2001 semester. The table summarizes the first class of Fellows by major, by level of schooling (either graduate or undergraduate), and by gender. Based on the statistics from the table, the ratio of engineering/science/math Fellows to education Fellows is 9 to 5. In the fall semester, there were 5 schools participating in the project with 6 teachers (one school had 2 teachers participating from the second week of the semester). Therefore, permanent assignments were made placing one education fellow and 2 engineering/math/science Fellows in each of the 5 schools. At the end of the semester, a sixth school was added and efforts began to add second teachers at all participating schools. This was mainly due to the successful recruiting efforts that took place in the fall semester, which resulted in an additional 3 engineering (mechanical and electrical) Fellows, and 3 education (math, science, and leadership) Fellows.

Table No. 1 - ATA Fellow Demographics in Fall 2001 Semester

\begin{tabular}{|c|c|c|c|c|c|}
\hline Major & $\begin{array}{c}\text { Total Number } \\
\text { Participating }\end{array}$ & $\begin{array}{c}\text { Graduate } \\
\text { Students }\end{array}$ & $\begin{array}{c}\text { Undergraduate } \\
\text { Students }\end{array}$ & Female & Male \\
\hline Industrial Engineering & 6 & 1 Master, 1 PhD & 4 & 5 & 1 \\
\hline Civil Engineering & 1 & & 1 & 1 & \\
\hline Environmental Science & 1 & & 1 & 1 & \\
\hline Math & 1 & & 1 & 1 & \\
\hline Technology Education & 1 & 1 Master & & 1 & \\
\hline Science Education & 4 & 3 PhD & 1 & 3 & 1 \\
\hline Total & 14 & $\begin{array}{c}\text { Masters, } 4 \\
\text { PhD }\end{array}$ & 8 & 12 & 2 \\
\hline
\end{tabular}

\section{Purpose and Description of ATA Course}

ATA contains numerous components that facilitate the education and training of Fellows into effective and exemplary science and mathematics teachers who can use their technical background to develop inquiry-based learning activities for secondary students. Upon matriculation from ATA, Fellows are able to fuse authentic learning and instructional technology together in order to connect real-world issues with teaching basic core knowledge relevant to the students' community and world. Through ATA, Fellows directly experience designing and developing inquiry-based activities using the most current instructional technology, as well as directly implementing these activities into secondary classrooms with teachers and university faculty acting as mentors and guides. Figure 1 illustrates the main components of ATA that are important to Fellows: Instructional Preparation, Technology Preparation, Technology Infrastructure, Secondary Teachers, Secondary Student, and University Faculty. These components are intertwined through the inquiry-based activities and projects that the Fellows, teachers, and faculty develop and implement together as a team.

Proceedings of the 2002 American Society for Engineering Education Annual Conference \& Exposition Copyright (C) 2002, American Society for Engineering Education 
First-year Fellows spend the fall semester in training, classroom observations, and direct interactions with teachers and students. Training includes the Fellows course "Implementing Authentic Science and Mathematics Activities in Secondary Schools" that presents basic educational principles and theory congruent with authentic learning, as well as how to design, develop, implement, and assess hands-on, inquiry-based activities. Moreover, the Fellows visit each of the secondary teacher's classrooms to observe and participate in the classroom. Some of the second-year Fellows take an advanced course in instructional technology.

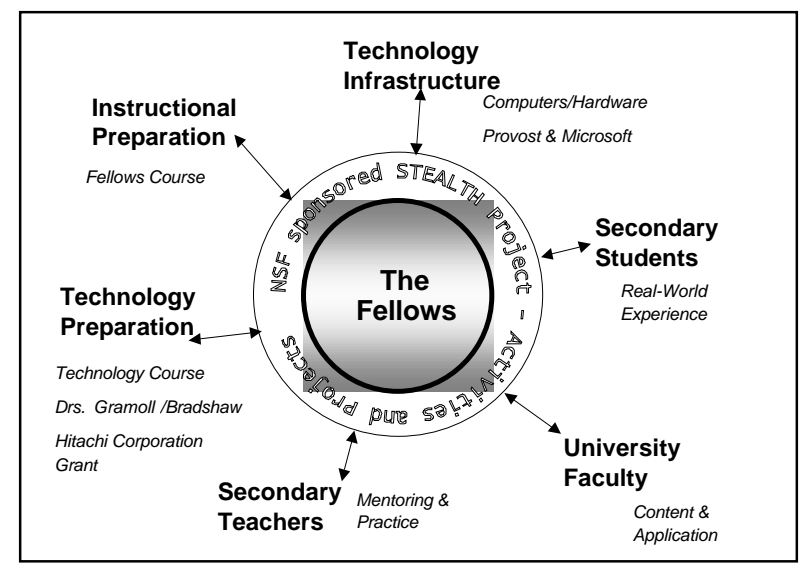

Figure 1: ATA structure illustration.

At the end of the fall semester, Fellow-teacher-faculty teams were formed and began developing extensive activities for the teachers' classes. Throughout the spring semester, the teams continually work on the activities, and the Fellows, with the teacher's guidance, implement them in the secondary classrooms. A weekly seminar in the spring semester allow the Fellows, teachers, and faculty to assess and share current progress and developments.

In fall of 2001, a 3 credit hour course "Implementing Authentic Science and Mathematics Activities in Secondary Schools" consisting of two 50 minute sessions/discussions per week and a weekly practicum (e.g., 10 hours/week in secondary classrooms observing, interacting with students \& assisting teachers) was used to prepare first-year Fellows for effective teaching in the secondary classroom and to teach them how to develop effective and appropriate activities. The general structure consists of thirty sessions: ten sessions on educational concepts, theory, and assessment; ten sessions on design and implementation of science \& math curricula with an emphasis on educational technology; and ten sessions on local, state and national curriculum standards (referred to as state PASS objectives), educational practices and methods, and pragmatic \& logistical secondary education issues. Fellows spend several hours per week outside of class researching, designing, and developing individual activities and projects.

The course was team-taught by Drs. O'Hair, Rhoads, and Nanny, along with secondary administrators and secondary teachers. Dr. Nanny was the instructor of record for the engineers Proceedings of the 2002 American Society for Engineering Education Annual Conference \& Exposition Copyright (C) 2002, American Society for Engineering Education 
and science/mathematics majors and Dr. O'Hair was the instructor of record for the education majors. The teachers and administrators provided instruction on state and national curriculum standards or the PASS objectives, good educational teaching practices and methods, classroom management practices, and school administration issues.

The course schedule has been included in the Appendix, as well as an education bibliography that was supplied to all the course attendees.

\section{Results of First Offering}

Overall, it is felt that the first offering of the course was successful. No students dropped the course. All students agreed on a final reflection piece that they knew significantly more about teaching and had more confidence at the end of the course than at the beginning.

During several formative evaluation sessions, using plus/deltas, brainstorming, and reflection writings, there were several recommendations that were utilized in the latter portions of the semester and many more that will be incorporated in the next offering of the course in fall of 2002. These include the fact that a text was not assigned and paper handouts were heavily relied upon. In the next course offering, the book Foundations of Democratic Education ${ }^{5}$ will be the required text. Teachers and principals from participating schools will be heavily encouraged to attend the course. This is not only for their benefit, but also for the benefit of the Fellows. Teacher and principal input to discussions and evaluations of exercises provide a valuable resource and insight to the Fellows. The amount of time that each Fellow spends rotating through the schools will be reduced from two weeks at each school to one week at each school. This will allow for the team assignments to be made at a much earlier date in the semester and the Fellows can begin working with their assigned classes sooner. The Fellows felt they had a good understanding of the school and the classes at the end of the first week and really wanted to get started with their permanent assignments much sooner. Fellows indicated that using material that would benefit the teacher immediately in the course assignments would benefit not only the Fellow, but also the teacher. Final projects in the fall semester were subsequently based on actual state requirements of objectives for each of the classes served by the Fellows. In the next offering, even initial exercises will be based on the Oklahoma State PASS objectives and not random scientific or mathematical theories. This allows for the student to see an immediate need in the classroom, as well as to allow the Fellow to teach at a very early point in their project training. More team building will be incorporated earlier. Despite the use of a ropes course and several team-building exercises, the end of the semester came and some of the Fellows still were not sure about their final team assignments. That is, not all Fellows felt they knew their permanent partners very well. Lastly, new team-oriented space has been allocated to the project. This space will allow for outside of class meeting time for the Fellows, as well as for the teachers participating in the project. This space will also allow for our full time coordinator to be more involved in the day-to-day contact of each of the Fellows. Lastly, this space allows the ATA GK12 program to co-exist with the Adventure Engineering GK-12 project, also at the University of 


\section{Oklahoma.}

\section{Differences of Cultures}

There are several cultural issues to discuss with respect to this course. One is the act of combining researchers in a course for grade scenario. The benefit of offering a course for grade allows students to obtain credit for a learning experience. Though it is beneficial to some degree to offer this type of course for credit, it confuses the professional relationships. The relationship of graduate or research assistant to principal investigator is different than the relationship of pupil to teacher. In fact, the idea of distributing grades was quite stressful to several of the education students. Therefore, not only could a student earn a bad grade, ultimately they felt they could be fired from the project - a double whammy, so to speak.

In addition, there is a culture difference from engineering/scientists/mathematicians to education majors. Just the fact that the class was separated into two class periods was quite a bit different for one culture than the other. The education majors are use to taking courses on single nights, whereas the engineering students tended to have combinations of courses offered in single and multiple sessions. From an instructor perspective, the education instructor preferred once a week offerings and the engineering instructors preferred multiple time offerings. Seeing these differences and working within the parameters has been beneficial to all involved.

\section{Conclusions}

Any new course offering takes patience from both sides; instructor and student. This course was no exception. There will be multiple enhancements and refinements made for the next offering in fall of 2002. Overall, the students learned about themselves, their peers, the project, and education in general.

\section{Bibliography}

1. Darling-Hammond, L. (2000). "Teacher Quality and Student Achievment: A Review of State Policy Evidence", Education Policy Analysis Archives, vol. 8 (1), http://epaa.asu.edu/etaa/v8.

2. Phipho, C. (1998). “A "Real” Teacher Shortage”, Phi Delta Kappan, vol. 80 (3), pg. 181-185.

3. Newmann, F. M., \& Wehlage, G. G. (1995). Successful school restructuring. Alexandria, VA: Association for Supervision and Curriculum Development.

4. Newmann, F. M. \& Associates (1996). Authentic achievement: Restructuring schook for intellectual quality. San Francisco: Jossey-Bass.

5. O’Hair, M. J., McLaughlin, H. J., \& Reitzug, U. C. (2000). Foundations of democratic education. Fort Worth: Harcourt Brace.

\section{TERI REED RHOADS}

Teri Reed Rhoads is an Assistant Professor of Industrial Engineering at the University of Oklahoma. She also serves as the Assessment Advisor to the College of Engineering. Dr. Rhoads is actively involved in research with industry as well as with the National Science Foundation, the Department of Education and the Norman School District Foundation. Her 
areas of interest are engineering education and assessment as well as quality engineering. Dr. Rhoads received a B.S. degree in Petroleum Engineering from the University of Oklahoma in 1985, a Masters in Business Administration from the University of Texas of the Permian Basin in 1992, and a Ph.D. in Industrial Engineering from Arizona State University in 1999.

\section{MARK NANNY}

Dr. Nanny teaches undergraduate and graduate environmental science and environmental chemistry courses. He has over 23 research publications in the area of environmental chemistry, and has edited a book on Nuclear Magnetic Resonance Spectroscopy in Environmental Chemistry. In 1998 he received a fouryear NSF-CAREER award, that not only supports his scientific research, but also his high school outreach program, "Enhancing Environmental Education", (E3).

\section{MARY JOHN O'HAIR}

Dr. O'Hair has been involved in educational leadership and school renewal issues for over 15 years. She has over 40 publications and 7 books on the topic, as well as has won numerous national and international awards for her achievements. In the past years, Dr. O'Hair has secured $\$ 677,980$ in external and internal funding for educational renewal research and development. Over the past three years, she has given keynote addresses to educational and government leaders in Finland, Germany, Australia, Northern Ireland, Kuwait, South Africa and Bulgaria. She has served as the Associate Dean for Graduate Studies and Research in the College of Education at OU, and is the founder of O.N.E. and the international Center for School Renewal and Democratic Citizenship. Dr. O'Hair has supervised 7 Ph.D. students to completion.

\section{Appendix}

\section{Actual Course Schedule with Topical Details}

\begin{tabular}{|c|c|c|c|c|c|}
\hline Week & Date & Topic (s) & Instructor & $\begin{array}{l}\text { Reading } \\
\text { Assignments }\end{array}$ & $\begin{array}{l}\text { Project/ } \\
\text { Assignments }\end{array}$ \\
\hline 1 & $8-21$ & $\begin{array}{ll}\text { - } & \text { Intro. To Class \& } \\
& \text { Blackboard } \\
\text { - } & \text { ATA Program Eval. } \\
& \text { Comp. } \\
\text { - } & \text { Journals } \\
\text { - } & \text { Professionalism } \\
\end{array}$ & $\begin{array}{l}\text { Mark Nanny } \\
\text { Teri Reed-Rhoads } \\
\text { Jean Cate }\end{array}$ & & Site Tours \\
\hline 2 & $8-28$ & $\begin{array}{l}\text { Theoretical Found. Of } \\
\text { Authen. Learning }\end{array}$ & Mary John O'Hair & $\begin{array}{l}\text { O’Hair, McLaughlin, } \\
\text { \& Reitzug } \\
\text { Chp. 1-2;11-12 }\end{array}$ & Site Tours \\
\hline 3 & $9-04$ & $\begin{array}{ll}\text { - } & \text { T.F.A.L. cont'd } \\
\text { - } & \text { Self-Assessment }\end{array}$ & Mary John O'Hair & $\begin{array}{l}\quad \text { Apple \& Beane } \\
\text { Chp. 1-2 } \\
\text { O'Hair, Chp. } 5\end{array}$ & \\
\hline 4 & $9-11$ & $\begin{array}{ll}\text { - } & \text { Ice Breakers } \\
\text { - } & \text { Teaming Skills }\end{array}$ & $\begin{array}{l}\text { Teri Reed- } \\
\text { Rhoads }\end{array}$ & & \\
\hline & $9-16$ & Ropes Course & & & TEAM QUEST \\
\hline 5 & $9-18$ & $\begin{array}{l}\text { Learning Styles \& Develop. } \\
\text { Chara. }\end{array}$ & Jean Cate & & $\begin{array}{l}\text { Reflection Jounal } \\
\text { Due }\end{array}$ \\
\hline 6 & $9-25$ & $\begin{array}{l}\text { Group Processing \& } \\
\text { Cooperative Learning }\end{array}$ & Randy Averso & $\begin{array}{l}\text { Ch. 6-7 } \\
\text { O'Hair, Mc }\end{array}$ & \\
\hline
\end{tabular}

Proceedings of the 2002 American Society for Engineering Education Annual Conference \& Exposition Copyright (C) 2002, American Society for Engineering Education 


\begin{tabular}{|c|c|c|c|c|c|}
\hline \multirow[b]{2}{*}{7} & \multirow[b]{2}{*}{$10-02$} & & \multicolumn{3}{|c|}{ Laughlin, Reitzug } \\
\hline & & $\begin{array}{l}\text { Assessment } \\
\text { PASS- using Passport }\end{array}$ & Jean Cate & & $\begin{array}{l}\text { Sign up for Field } \\
\text { Trips: Pre-lesson } \\
\text { for F.T. } \\
\text { Reflection Journal } \\
\text { Due }\end{array}$ \\
\hline 8 & $10-09$ & $\begin{array}{l}\text { Lesson Plan Design \& } \\
\text { Interdisciplinary Application } \\
\text { Reflection: Cognitive Styles }\end{array}$ & $\begin{array}{l}\text { Randy Averso } \\
\text { Mark Nanny }\end{array}$ & & $\begin{array}{l}\text { Lesson using Field } \\
\text { Experiences to } \\
\text { present to the class }\end{array}$ \\
\hline 9 & $10-16$ & $\begin{array}{l}\text { Class Presentations over } \\
\text { Lesson Plans }\end{array}$ & Mark Nanny & & \\
\hline 10 & $10-23$ & Technology Integration & $\begin{array}{l}\text { Kurt Gramoll } \\
\text { Patrick Dennis }\end{array}$ & & \\
\hline 11 & $10-30$ & Field experience & Myriad Gardens & Gene Williams & $\begin{array}{l}\text { Reflection Journal } \\
\text { Due }\end{array}$ \\
\hline Special & $11-05$ & Field Experience & $\begin{array}{l}\text { Waste \& Water } \\
\text { Treatment Plant }\end{array}$ & Mark Nanny & \\
\hline 12 & $11-06$ & Field Experiences & $\begin{array}{l}\text { Sam Noble } \\
\text { History Museum } \\
\text { OKC Zoo }\end{array}$ & Wendy Gram & \\
\hline & & & & Allison Brody & \\
\hline 13 & $11-13$ & Scientific Method & Mark Nanny & & $\begin{array}{l}\text { Reflection Journal } \\
\text { Due }\end{array}$ \\
\hline 14 & $11-20$ & $\begin{array}{l}\text { Development of Authentic } \\
\text { Activities based on field } \\
\text { experiences and PASS } \\
\text { objectives }\end{array}$ & & & Second Lesson \\
\hline 15 & $11-27$ & $\begin{array}{l}\text { Cognitive styles of the } \\
\text { secondary students }\end{array}$ & Mark Nanny & & $\begin{array}{l}\text { Create teams for } \\
\text { Spring Semester } \\
\text { Reflection Journal } \\
\text { Due }\end{array}$ \\
\hline & & Cont'd & & & $\begin{array}{l}\text { Start planning } \\
\text { spring activities } \\
\text { with team }\end{array}$ \\
\hline 16 & $12-04$ & & & & $\begin{array}{l}\text { Final Assigned: } \\
\text { Portfolio }\end{array}$ \\
\hline
\end{tabular}

\section{Educational Bibliography}

Apple, M. W., \& Beane, J. A. (1995). Democratic schools. Alexandria, VA: Association for Supervision and Curriculum Development.

Boyer, E. (1994, March). What is an educated person? Keynote address at the annual meeting of the Association for Supervision and Curriculum Development, Washington D.C. 
Delpit, L. (1995). Other people's children: Cultural conflict in the classroom. New York: The New Press.

Dewey, J. (1916). Democracy and education. New York: Macmillan.

Fullan, M. G. (1993). Change forces: Probing the depths of educational change. New York: Teachers College Press.

Glickman, C. D. (1998). Renewing America's schools: A guide for school-based action. ( $2^{\text {nd }}$ Edition) San Francisco: Jossey-Bass.

Glickman, C. D. (1998). Revolutionalizing America's schools. San Francisco: Jossey-Bass.

Goodlad, J. I. (1994). Educational renewal: Better teachers, better schools. San Francisco: Jossey-Bass.

Kozol, J. (1991). Savage inequalities. New York: Crown.

Kozol, J. (1995). Amazing grace. New York: HarperPerennial.

Lee, V. E., \& Smith, J. B. (1994). High school restructuring and student achievement: A new study finds strong links. Issues in Restructuring Schools. University of Wisconsin: Center on Organization and Restructuring of Schools.

Levy, S. (1996). Starting from scratch: One classroom builds its own curriculum. Portsmouth, NH: Heinemann.

McIntyre, D. J., \& O’Hair, M. J. (1996). Reflective roles of the classroom teacher. Belmont, CA: Wadsworth.

Meier, D. (1995). The power of their ideas: Lessons for America from a small school in Harlem. Boston: Beacon Press.

Newmann, F. M. \& Associates (1996). Authentic achievement: Restructuring schools for intellectual quality. San Francisco: Jossey-Bass.

Newmann, F. M., \& Wehlage, G. G. (1995). Successful school restructuring. Alexandria, VA: Association for Supervision and Curriculum Development.

O'Hair, M. J., McLaughlin, H. J., \& Reitzug, U. C. (2000). Foundations of democratic education. Fort Worth: Harcourt Brace. 
O'Hair, M. J., \& Odell, S. J. (1995). Educating teachers for leadership and change. Newbury Park, CA: Corwin.

Schmoker, M. (1999). Results: The key to continuous school improvement. Alexandria, VA: Association for Supervision and Curriculum Development.

Sizer, T. R. (1992). Horace's school: Redesigning the American high school. Boston: Houghton Mifflin.

Wood, G. H. (1998). Schools that work: America's most innovative public education programs. New York: Penguin Books. 